\title{
Mengembangkan Sikap Rasa Ingin Tahu (Curiosity) Siswa pada Pelajaran Fisika Menggunakan Model Pembelajaran Flipped Classroom
}

\author{
Joko Krismanto Harianja \\ Magister Teknologi Pembelajaran, Universitas Pelita Harapan \\ Email: jkharianja@gmail.com
}

Received: 3 Maret 2020;

Accepted: 4 Mei 2020;

Published: 9 Mei 2020

DOI: http://dx.doi.org/10.29303/jpft.v6i1.1738

\begin{abstract}
Curiosity is one of the attitudes that needs to be developed in learning activities. This research proved hat students' curiosity can be developed by selecting appropriate learning models. The flipped classroom learning model is one of good models to develop curiosity. In this research the action research (CAR) class has been chosen as a research method to analyze the increase in curiosity and the value of learning outcomes in class 12 Physics learning activities. The treatment given is to provide opportunities for students to study independently outside the school schedule to study the material provided and find out all forms of information needed. Students have the opportunity to work together in class giving reports on their learning outcomes by making presentations in class. The instrument used for part of the data collection technique is in the form of observation sheets, questionnaire sheets and question sheets containing questions in accordance with the material being studied. The data analysis technique was carried out using descriptive and quantitative qualitative analysis. The results of the research show that students' curiosity and student learning outcomes can be improved by using these learning models. The obtained data analysis of the also shows that the implementation of the flipped classroom learning model provides very significant benefits.
\end{abstract}

Keywords: flipped classroom; classroom action research; curiosity

PENDAHULUAN

Belajar dapat diartikan sebagai keceriaan dalam mengejar sesuatu hal yang belum diketahui dengan cara yang menyenangkan dan menjadikan alam sekitar sebagai sumber belajar yang bisa juga dibaca sebagai alternatif sumber pengetahuan.

Menurut psikolog ternama Gagne, belajar didefinisikan sebagai seperangkat proses kognitif yang mengubah sifat stimulus lingkungan, melewati pengolahan imformasi, dan menjadi kemampuan baru (Nasution, 2018). Dengan kata lain belajar dapat diartikan sebagai suatu interaksi antara seorang individu dengan lingkungannya.

Rasa ingin tahu (curiosity) adalah bentuk motivasi intrinsik yang merupakan kunci dalam membina pembelajaran aktif dan eksplorasi secara spontan (Haryanto, 2019). Untuk alasan ini, pembelajaran yang digerakkan oleh rasa ingin tahu dan motivasi intrinsik telah ramai diperbincangkan sebagai dasar penting untuk pendidikan yang efisien (Nurhasanah, 2019). Dalam pendidikan, penerapan rasa ingin tahu dalam pembelajaran secara aktif akan meningkatkan motivasi belajar siswa dan bukan hanya itu saja, kegiatan pembelajaran pun menjadi menyenangkan. Rasa ingin tahu juga menjadi bagian yang sangat penting dalam menghadapi tantangan-tantangan pendidikan pada abad ke 21 (Agustian et al. 2019).

Rasa ingin tahu (curiosity) merupakan suatu sikap untuk mengetahui dan terus mencari tahu terhadap suatu permasalahan. Rasa ingin tahu adalah cara berpikir, sikap dan perilaku yang mencerminkan penasaran dan keingintahuan terhadap segala hal yang dilihat, didengar, dan dipelajari secara lebih mendalam (Diana et al. 2020). Rasa ingin tahu merupakan modal awal bagi siswa 
dalam proses pembelajaran (Setiyadi, 2018). Dengan keingintahuan yang tinggi maka siswa akan belajar lebih guna memenuhi kehausan akan pengetahuan yang ingin diketahui. Melalui kaingintahuannya siswa akan mulai belajar dan menemukan (Prasetyo \& Nisa, 2018). Di dalam pendidikan, khususnya dalam proses pembelajaran, sikap rasa ingin tahu harus dikembangkan dengan baik sehingga siswa mampu mengembangkan dan memperluas wawasan pengetahuan mereka.

Dalam kemendiknas, rasa ingin tahu didefinisikan sebagai suatu sikap serta tindakan yang selalu berupaya untuk mengetahui lebih mendalam dan meluas tentang sesuatu yang sedang dipelajari. Sumani dan Harinto (Waluyo \& Siswanto, 2019) menyatakan dengan jelas bahwa sikap rasa ingin tahu merupakan suatu keinginan yang timbul dalam diri individu untuk menyelidiki dan mencari pemahaman terhadap rahasia alam atau suatu peristiwa sosial tertentu yang sedang terjadi.

Rasa ingin tahu merupakan salah satu ciri yang menjadi penentu dalam prestasi belajar maupun prestasi kreatif seorang siswa. Menurut (Listriania \& Aini, 2019), indikator siswa memiliki rasa ingin tahu adalah sebagai berikut: (1) siswa mampu merespon secara positif terhadap unsur yang baru di lingkungan mereka dengan cara mendekati, (2) memeriksa dan memperhatikannya, (3) mengamati lingkungan untuk mencari pengalaman baru, dan (4) penuh perhatian terhadap rangsangan yang ada.

Menurut Alita et al. (2019), indikator sikap rasa ingin tahu siswa di kelas adalah: (1) terciptanya suasana kelas yang mengundang rasa ingin tahu, (2) menunjukkan berpikir secara kritis, logis, dan kreatif, (3) menunjukkan keterampilan memperhatikan, berbicara, membaca dan menulis, (4) membuka pemikiran siswa terhadap hal-hal baru atau pun hal-hal yang sedang dipelajari, (5) banyak memberikan pertanyaa, (6) memiliki sikap tertarik terhadap pembelajaran dan tidak menerima pembelajaran sebagai sesuatu yang membosankan, dan (7) terlihat senang terhadap pembelajaran serta memahami pembelajaran.

Berdasarkan uraian di atas, maka dapat disimpulkan bahwa indikator sikap rasa ingin tahu untuk diamati oleh peneliti sebagai deskriptor adalah sebagai sebagai berikut: (1) aktif bertanya kepada guru dan teman terkait materi pembelajaran, (2) memiliki sikap yang antusias mencari jawaban, (3) memberikan perhatian yang intesif terhadap objek yang sedang diamati dan (4) memiliki sikap yang antusias terhadap proses sains.

Adapun kriteria yang dapat digunakan untuk mengetahui apakah siswa memiliki sikap rasa ingin tahu atau tidak adalah sebagai berikut, (i) mendengarkan penjelasan dengan seksama, (ii) mampu bertanya tentang apa yang belum dimengerti dan yang baru diketahui, (iii) memperhatikan bahan ajar guru, terutama media yang diguakan dalam poses pembelajaran, dan (iv) antusias siswa untuk mencoba menyentuh hal-hal yang baru diketahui serta keaktifan siswa dalam mengikuti pelajaran serta rasa senang mengikuti setiap pembelajaran.

Tujuan dari penelitian ini adalah untuk mengetahui apakah dengan mengimplementasikan model pembelajaran flipped classroom sikap rasa ingin tahu siswa sebagai salah satu standar kompetensi dalam pembelajaran dapat dikembangkan atau ditingkatkan dan untuk menganalisa apakah dengan meningkatnya sikap rasa ingin tahu siswa akan meningkatkan prestasi siswa secara akademik.

Model Pembelajaran Flipped classroom adalah salah satu model 
pembelajaran yang mengandalkan metode pembelajaran yang berpusat pada siswa (student centered) dengan tujuan untuk meningkatkan efektifitas pembelajaran (Widodo, 2017). Dalam implementasi model pembelajaran flipped classroom, pemanfaatan teknologi adalah salah satu faktor yang mendukung proses pembelajaran, karena dengan demikian siswa dengan mudah mengakses materi pembelajaran kapanpun dan dimanapun. Sedangkan waktu pembelajaran di kelas digunakan siswa untuk berkolaborasi dengan rekan-rekan proyek, keterampilan praktik, dan menerima umpan balik tentang kemajuan mereka (Ishak et al. 2019).

\section{Model Flipped classroom} memberikan apa yang umumnya di lakukan di kelas dan apa yang umumnya dilakukan sebagai pekerjaan rumah kemudian dibalik atau ditukar (Chandra \& Nugroho, 2017). Siswa membaca materi, memperhatikan dan mendengarkan video pembelajaran sebelum mereka datang ke kelas dan mereka mulai berdiskusi, saling bertukar pengetahuan dan informasi, menyelesaikan masalah, dengan bantuan siswa lain maupun guru, model pembelajaran ini secara tidak langsung melatih siswa mengembangkan kefasihan prosedural jika diperlukan, inspirasi dan membantu mereka dengan proyek-proyek yang menantang dengan memberikan kontrol belajar yang lebih besar (Ishak, Thanthwi; Kurniawan, Rudi; Zainuddin, 2019).

Secara praktiknya, di dalam metode pembelajaran flipped classroom, siswa memperoleh pengetahuan awal sebelum berada di kelas, dengan kata lain mereka mempersiapkan pelajaran di rumah untuk mendapatkan informasi dan pengetahuan sesuai dengan materi yang dipersiapkan oleh guru berdasarkan rencana pembelajaran yang telah dirancang (Asri et al. 2018). Persiapan untuk mendapatkan informasi sesuai dengan materi yang dipelajari yaitu media yang telah dipersiapkan berupa video. Ketika berada di dalam kelas, siswa menggunakan waktu yang ada untuk berlatih dan menerapkan konsep serta ide melalui interaksi dengan teman atau berdiskusi dengan guru. Setelah proses pembelajaran di kelas selesai, siswa merenungkan umapan yang telah mereka terima ketika berada di dalam kelas dan menggunakan ini untuk mengembangkan hasil belajar mereka. Hal ini adalah proses refleksi terhadap yang telah dipelajari (Chandra \& Nugroho, 2017).

\section{METODE PENELITIAN}

Metode penelitian yang dilakukan pada penelitian ini adalah penelitian tindakan kelas (PTK). Model penelitian tindakan kelas yang dipilih adalah model siklus yang dilakukan berulang-ulang dan berkelanjutan (siklus spiral) yang dikemukakan oleh Kemmis dan Robin Mc. Taggart (Fitria et al. 2019). Alur penelitian pada model Kemmis dan Mc Taggart terdiri dari empat kegiatan pokok, yaitu perencanaan, pelaksanaan, pengamatan dan refleksi. Dalam penelitian ini, penulis yang juga berperan sebagai guru meneliti sendiri praktek pembelajaran yang dilakukan di alam kelas melalui tindakan-tindakan yang telah direncanakan, dilaksanakan dan dievaluasi. Pada saat pengamatan terhadap pelaksanaan pembelajaran, penulis dibantu oleh guru lain yang mengajar mata pelajaran yang sama sebagai pengamat. Tujuan digunakannya penelitian tindakan kelas ini adalah untuk menganalisa pengembangan sikap rasa ingin tahu siswa, mengetahui dan meningkatkan mutu hasil pembelajaran Fisika dengan menerapkan metode pembelajaran flipped classroom dan dengan menggunakan multimedia presentasi yang diharapkan pada akhirnya akan memberikan dampak yang positif pada hasil belajar siswa. 
Fisika merupakan salah tahu mata pelajaran IPA yang mempelajari suatu sifat dan gejala-gejala alam. Mata pelajaran fisika sangat berkaitan dengan kehidupan seharihari (Febriani et al. 2019). Bagi para siswa mempelajari fisika secara khusus dapat membantu dalam memecahkan masalah dalam kehidupan sehari-hari yang berkaitan dengan fisika (Widiawati et al. 2018). Selain itu, melalui pembelajaran Fisika, siswa diharapkan mampu membuktikan suatu teori atau konsep yang telah ada sebelumnya. Belajar Fisika juga dapat meningkatkan kemampuan berpikir kritis, menjadikan siswa secara aktif, kreatif, dan inovatif (Lidiana et al. 2018).

Penulis sangat mengharapkan adanya perubahan, perbaikan dan peningkatan pada proses pembelajaran di kelas. Penelitian tindakan kelas ini merupakan salah satu bentuk penelitian yang bersifat reflektif dengan melakukan tindakan-tindakan yang tepat dan dilaksanakan secara kooperatif dan kolaboratif.

Subjek penelitian ini adalah siswa kelas 12 yang mengambil mata pelajaran Fisika salah satu SMA swasta di Jawa Barat dengan jumlah siswa sebanyak 7 orang siswa laki-laki. Sebagai informasi tambahan bahwa kurikulum yang digunakan oleh sekolah tersebut adalah kurikulum satuan pendidikan kerjasama (SPK), yaitu perpaduan antara kurikulum nasional dan kurikulum Diploma Program International Baccalaurete (IBDP).

Dalam pembelajaran ini, siswa diberikan kesempatan untuk belajar secara kolaboratif dan kooperatif di dalam kelompok kecil yang terdiri dari 2 atau 3 orang per kelompok. Topik yang sedang dibahas adalah Energy Production yang terdiri dari beberapa subtopik. Siswa diberikan bahan pembelajaran yang bersesuaikan dengan materi yang telah ditentukan untuk masing-masing kelompok dalam bentuk video atau bahan-bahan bacaan dari berbagai sumber. Selama proses pembelajaran, siswa akan melakukan kegiatan pembelajaran flipped classroom di mana siswa belajar secara independen di rumah mereka. Hasil pembelajaran dirangkumkan di dalam bentuk presentasi multimedia menggunakan aplikasi power point. Ketika berada di dalam kelas, setiap kelompok akan memberikan presentasi di hadapan guru dan siswa yang lain. Setelah melakukan presentasi hasil belajar, akan diberikan kesempatan kepada siswa lain untuk melakukan tanya jawab. Setiap kelompok diberikan waktu selama seminggu (lima kali tatap muka) untuk mempresentasikan hasil pembelajaran dengan metode pembelajaran flipped classroom.

Penelitian ini dilaksanakan dengan empat siklus tindakan kelas. Pada tiap-tiap siklus dilakukan tiga kegiatan pembelajaran, yaitu presentasi, diskusi tanya jawab dan mengerjakan soal latihan berhubungan dengan materi yang sedang didiskusikan. Kegiatan yang dilakukan pada siklus pertama menjadi dasar penentu untuk kegiatan pembelajaran pada siklus berikutnya. Pada bagian akhir kegiatan pembelajaran siklus pertama dilakukan evaluasi dan refleksi dengan rekan sekerja yang menjadi pengamat (observer) untuk mengetahui efektivitas, kreativitas siswa dan bila memungkinkan untuk mengetahui kemungkinan berbagai kesulitan atau kendala yang dijumpai.

Teknik pengambilan dan pengumpulan data pada penelitian ini dilakukan dengan beberapa metode yang berbeda. Pertama dengan metode observasi langsung di lapangan, yaitu dengan mencatat setiap kegiatan yang dilakukan siswa selama dalam kegiatan pembelajaran seperti ketika mempresentasikan materi hasil dan dalam 
kegiatan diskusi tanya jawab. Hasil observasi secara langsung akan dicatat pada lembar aktifitas siswa dalam kategori sikap rasa ingin tahu. Metode yang kedua yaitu dengan mengumpulkan data melalui pertanyaan melalui kuesioner yang diberikan kepada siswa secara online melalui google form. Untuk mengetahui hubungan antara berkembangnya sikap rasa ingin tahu dengan prestasi hasil belajar siswa, teknik pengumpulan data dilakukan dengan mencatat nilai hasil belajar siswa melalui tes yang diberikan pada saat prasiklus, akhir siklus 1 dan akhir siklus 3

Dalam penelitian ini, analisa data yang dilakukan untuk melihat peningkatan rasa ingin tahu dengan model pembelajaran flipped classroom, yaitu dengan menggunakan analisa kualitatif deskriptif dan kuantitatif. Analisa kualitatif deskriptif yaitu analisa yang dilakukan terhadap data hasil survei kegiatan pembelajaran siswa selama di dalam kelas selama proses penelitian tindakan kelas berlangsung. Sedangkan analisa kuantitatif merupakan analisa data hasil observasi belajar siswa berdasarkan nilai hasil belajar pra-siklus, siklus I dan siklus III dengan tujuan untuk melihat apakah pengembangan sikap rasa ingin tahu memiliki hubungan dengan peningkatan nilai hasil belajar siswa.

Penelitian ini dapat dikatakan berhasil apabila aspek indikator sikap rasa ingin tahu siswa minimum berada dalam rentang nilai kategori baik. Kriteria yang digunakan dalam peneltian ini adalah konversi skor minimum 9. Kategori kriteria penelitian ini dapat dilihat pada Tabel 1 di bawah ini.

Tabel 1. Kriteria Penskoran

\begin{tabular}{cc}
\hline Interval Skor & Keterangan \\
\hline $1-4$ & Kurang \\
$5-8$ & Cukup \\
$9-12$ & Baik \\
$13-16$ & Sangat Baik \\
\hline
\end{tabular}

Berdasarkan Tabel 1 di atas dapat dengan jelas dinyatakan bahwa apabila siswa memperoleh skor pada interval 5 - 12, maka dinyatakan memiliki sikap rasa ingin tahu yang cukup. Jika skor siswa berada pada interval $13-16$, maka siswa dinyatakan memiliki sikap rasa ingin tahu yang sangat baik.

Instrumen yang digunakan pada penelitian in adalah berupa lembar observasi yang digunakan untuk menilai bagaimana perkembangan rasa ingin tahu sebagai hasil dari implementasi model pembelajaran flipped classroom. Di samping itu penulis juga merancang instrumentasi berupa kuesioner yang diberikan kepada siswa untuk mengetahui apakah implementasi model pembelajaran flipped classroom memberikan pengaruh positif terhadap siswa untuk meningkatkan rasa ingin tahu mereka, serta instrumen soal yang akan diujikan untuk mengetahui apakah model pembelajaran flipped classroom memberikan pengaruh terhadap prestasi nilai belajar Fisika siswa.

\section{HASIL DAN PEMBAHASAN}

Berdasarkan penelitian yang telah dilakukan, peningkatan sikap rasa ingin tahu dan nilai hasil belajar siswa dalam pembelajaran Fisika dengan topik Energy Production menggunakan metode flipped classroom memberikan hasil yang memuaskan dan sesuai dengan apa yang telah direncanakan.

Penelitian ini dilakukan dalam 3 siklus, di mana pada setiap siklus dilakukan 5 kali tatap muka di dalam kelas dengan pelaksaan 5 kali 45 menit. Setiap kegiatan pembelajaran yang telah dilaksanakan di dalam kelas bersesuaian dengan kegiatan yang telah dituangkan dalam rencana perencanaan pembelajaran (RPP).

Secara keseluruhan hasil yang diperoleh dari penelitian ini menunjukkan 
bahwa implementasi model pembelajaran flipped classroom dalam meningkatkan sikap rasa ingin tahu berjalan dengan baik dengan sejumlah perbaikan-perbaikan yang dilakukan pada tiap siklusnya serta dapat mencapai kriteria keberhasilan penelitian seturut dengan indikator sikap rasa ingin tahu.

Berdasarkan kegiatan pembelajaran yang telah dilakukan di dalam kelas, diperoleh data observasi sikap rasa ingin tahu siswa dalam siklus I, siklus II dan siklus III pada Tabel 2 di bawah ini.

Tabel 2. Data Observasi Sikap Rasa Ingin Tahu Siswa per Siklus

\begin{tabular}{lccc}
\hline Kriteria & Siklus I & Siklus II & Siklus III \\
\hline Kurang & $28 \%$ & $14 \%$ & $0 \%$ \\
Cukup & $44 \%$ & $14 \%$ & $0 \%$ \\
Baik & $14 \%$ & $44 \%$ & $57 \%$ \\
Sangat & $14 \%$ & $28 \%$ & $43 \%$ \\
Baik & & &
\end{tabular}

Dari informasi yang dapat dilihat pada

Tabel 2 di atas, peningkatan sikap rasa ingin tahu siswa terjadi secara bertahap dari siklus I sampai kepada siklus III. Pada siklus III terlihat tidak ada lagi siswa yang memiliki sikap rasa ingin tahu pada kriteria kurang dan cukup. Hal ini mengindikasikan bahwa implementasi metode pembelajaran flipped classroom telah berhasil mendorong siswa untuk memiliki dan mengembangkan sikap rasa ingin tahu, khususnya dalam pelajaran Fisika.

Peningkatan sikap rasa ingin tahu juga dapat dilihat dari skor rata-rata hasil skala sikap pada Tabel 3. Dari Tabel 3 dapat diketahui dengan jelas bahwa sikap rasa ingin tahu siswa kelas 12 mengalamai peningkatan yang signifikan pada setiap siklus.

Tabel 3. Peningkatan Sikap Rasa Ingin Tahu

\begin{tabular}{cccc}
\multicolumn{3}{c}{ Siswa } \\
\hline No. & Siklus & Skor Rata-rata & Kriteria \\
\hline 1. & I & 6.85 & Cukup \\
2. & II & 10.42 & Baik \\
3. & II & 13.14 & Sangat Baik \\
\hline
\end{tabular}

Berdasarkan data kuesioner sikap rasa ingin tahu siswa, setelah dilakukan kegiatan pembelajaran menggunakan metode flipped classroom dari siklus I sampai kepada siklus III diperoleh hasil pada Tabel 4 di bawah ini.

Tabel 4. Data Kuesioner Sikap Rasa Ingin Tahu

\begin{tabular}{ccc}
\multicolumn{3}{c}{ Siswa } \\
\hline Kriteria & Jumlah & Persentase \\
\hline Sangat Rendah & 0 & $0 \%$ \\
Rendah & 0 & $0 \%$ \\
Sedang & 0 & $0 \%$ \\
Tinggi & 3 & $43 \%$ \\
Sangat Tinggi & 4 & $57 \%$ \\
\hline
\end{tabular}

Dari data yang terdapat pada tabel di atas dapat diketahui bahwa persentase siswa yang memiliki sikap rasa ingin tahu yang sangat tinggi sebesar 57\% dan persentase siswa yang memiliki sikap rasa ingin tahu yang tinggi adalah $43 \%$. Tidak ada siswa yang memiliki sikap rasa ingin tahu pada kriteria sedan rendah dan sangat rendah. Data yang diperoleh melalui observasi dengan data hasil kuesioner siswa telah menunjukkan adanya kesesuaian dalam meningkatkan sikap rasa ingin tahu seperti yang diharapkan.

Berdasarkan data hasil belajar siswa yang diperoleh sebelum (pra-siklus) dilakukankan kegiatan pembelajaran flipped classroom sampai kepada siklus terakhir, terlihat ada peningkatan hasil belajar yang signifikan yang dituangkan pada gambar diagram batang berikut ini.

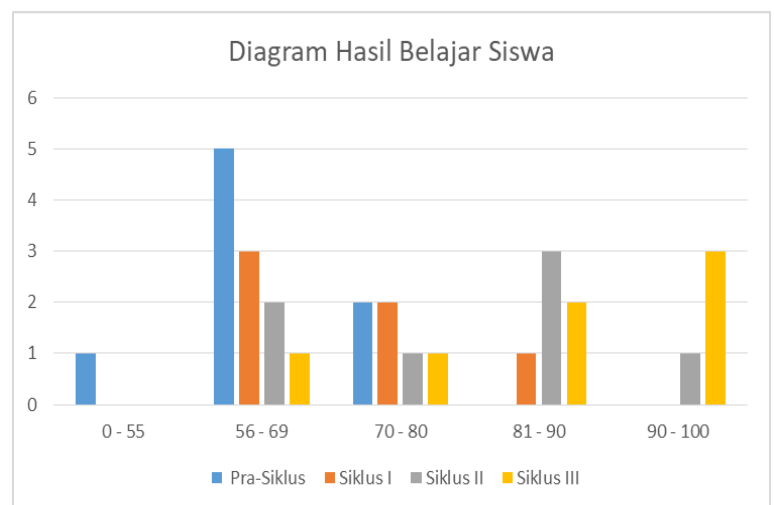

Gambar 1. Diagram Hasil Belajar Siswa 
Sebagai informasi penting yang perlu diketahui untuk pelajaran Fisika kelas 12 dengan menggunakan IBDP (International Baccalaurette) curriculum, nilai batas kelulusan yang telah ditetapkan adalah lebih besar dari 65. Berdasarkan data hasil belajar siswa sebelum kegiatan pembelajaran dengan menggunakan metode flipped classroom pada diagram batang yang disediakan pada Gambar 1 dapat dilihat terjadi peningkatan hasil belajar siswa yang diperoleh dari tes yang diberikan pada saat pra-siklus, siklus I, siklus II dan siklus III. Pada siklus III, siswa yang mendapat nilai lebih besar atau sama dengan nilai kelulusan (65) adalah $86 \%$ dan $14 \%$ tidak mencapai nilai kelulusan.

Kegiatan pembelajaran dengan menggunakan model flipped classroom sangat mendukung peningkatan sikap rasa ingin tahu siswa. Hal ini terlihat ketika siswa sedang melakukan kegiatan diskusi tanya jawab. Ketika ada siswa yang sedang mempresentasikan hasil belajar kolaboratif dan kooperatif, siswa tersebut mampu memberikan penjelasan yang lebih luas dengan tambahan teori pendukung yang serta contoh-contoh dan aplikasi yang diperoleh dari berbagai sumber referensi sehingga membuat siswa lain yang mendengarkan, menyimak dengan seksama serta memperhatikan presentasi tersebut menjadi sangat berantusias untuk memberikan pertanyaan-pertanyaan dengan tujuan untuk mendapatkan informasi yang lebih banyak dan untuk mencari jawaban atas rasa ingin tahu mereka.

Berdasarkan data yang telah dikumpulkan pada penelitian ini, maka diperoleh adanya peningkatan sikap rasa ingin tahu dan peningkatan hasil belajar setelah menggunakan metode pembelajaran flipped classroom. Berdasarkan data-data di atas, maka diperoleh presentasi keadaan peningkatan sikap rasa ingin tahu siswa dan peningkatan hasil belajar siswa dapat sebagai berikut.

Tabel 5. Peningkatan Hasil Belajar dan Rasa Ingin Tahu

\begin{tabular}{rrrrrr}
\hline \multicolumn{2}{c}{ Siklus I } & \multicolumn{2}{c}{ Siklus II } & \multicolumn{2}{c}{ Siklus III } \\
\hline HB & RIT & HB & RIT & HB & RIT \\
\hline $57 \%$ & $28 \%$ & $71 \%$ & $72 \%$ & $86 \%$ & $100 \%$ \\
\hline Ken
\end{tabular}

Keterangan:

HB - Hasil Belajar

RIT - Rasa Ingin Tahu

Dari hasil pengamatan terhadap siklus I, siklus II dan siklus II hasil observasi rasa ingin tahu, kuesioner rasa ingin tahu dan hasil belajar siswa telihat manfaat pembelajan dengan metode flipped classroom untuk mengembangkan dan meningkatkan sikap rasa ingin tahu siswa, karena di dalam proses kegiatan pembelajaran setiap siswa dituntut untuk berbagian dengan aktif dalam menggali pengetahuan baik secara individu maupun secara kooperatif.

Hasil termuan yang diperoleh pada penelitian ini sejalan dengan penelitian yang telah dilakukan sebelumnya oleh Nurpianti et al. (2019) yang menggunakan model pembelajaran flipped classroom untuk meningkatkan keterampilan berpikir kritis pada siswa. Berdasarkan penelitian yang dilakukan, dengan menerapkan model pembelajaran flipped classroom berbasis Pendidikan untuk Pembangunan Berkelanjutan (PPB) dapat meningkatkan keterampilan berpikir kritis dengan kategori sedang secara keseluruhan (Nurpianti et al. 2019).

Temuan pada penelitian yang dilakukan oleh Rahajeng et al. (2018) menunjukkan bahwa model pembelajaran group investigation flipped classroom lebih efektif dalam meningkatkan kemampuan berpikir kreatif siswa dibandingkan dengan model pembelajaran traditional flipped classroom maupun model pembelajaran direct instruction (Rahajeng et al. 2018). Kemampuan berpikir kreatif siswa yang 
lebih tinggi pada kelas yang belajar menggunakan model pembelajaran group investigation flipped classroom merupakan dampak dari pembelajaran tatap muka dengan group investigation dan pembelajaran online dalam membantu proses konstruksi pengetahuan pada struktur kognitif siswa agar lebih bermakna sehingga berpengaruh terhadap kemampuan berpikir siswa termasuk di dalamnya kemampuan berpikir kreatif ( Rahajeng et al. 2018)

Hasil temuan penelitian yang dilakukan oleh Rani (2018) menunjukkan bahwa peningkatan keterampilan higher order thinking mahasiswa dapat dilakukan melalui proses belajar di dalam kelas yang menerapkan diskusi dan metode problem solving dengan dukungan implementasi model pembelaajran flipped classroom. Bekal pengetahuan siswa dari eksplorasi di luar kelas memungkinkan pembelajaran di dalam kelas mengembangkan kemampuan berpikir tingkat tinggi, karena mahasiswa telah memiliki pengetahuan, pemahaman, dan penerapan dan di dalam kelas bisa ditingkatkan menjadi analisis, evaluasi dan menciptakan sesuatu yang baru. Penerapan model pembelajaran flipped classroom mempengaruhi peningkatan kemampuan mahasiswa dalam pemecahan masalah dengan menuntut mahasiswa untuk sekaligus mengembangkan creative thinking, critical thinking dan logical thinking (Rani, 2018).

$\begin{array}{llr}\text { Oleh karena } & \text { itu, dengan } \\ \text { membandingkan hasil } & \text { temuan pada } \\ \text { penelitian-penelitian } & \text { yang telah } \\ \text { dilaksanakan dengan } & \text { mengembangkan }\end{array}$
model pembelajaran flipped classroom untuk meningkatkan kemampuan kognitif siswa pada tingkat pendidikan menengah dan tinggi, maka dapat diketahui bahwa model pembelajaran flipped classroom memberikan pengaruh positif untuk meningkatkan kemampuan berpikir maupun rasa ingin tahu siswa. Model pembelajaran flipped classroom memberikan kesempatan kepada siswa untuk dapat berkembang secara aktif dalam proses pembelajaran.

Dalam penelitian ini dapat dikatakan bahwa model pembelaran flipped classroom memberikan kesempatan kepada siswa untuk mengembangkan rasa ingin tahunya dengan baik.

\section{PENUTUP}

Berdasarkan penelitian yang telah dilakukan serta merujuk kepada hasil yang telah diperoleh, kegiatan pembelajaran dengan menggunakan model pembelajaran flipped classroom memberikan manfaat yang baik untuk membantu meningkatkan sikap rasa ingin tahu siswa dan meningkatkan hasil belajar siswa pada pembelajaran Fisika.

Model pembelajaran flipped classroom telah memberikan sumbangsi yang besar dalam meningkatkan sikap rasa ingin tahu pada siswa. Data-data perolehan yang telah didapatkan sebagai hasil penelitian, baik dari observasi kegiatan pembelajaran, kuesioner yang diberikan kepada siswa dan hasil pembelajaran siswa melalui tes pra-siklus, siklus I, siklus II dan akhir siklus III secara jelas membuktikan bahwa ada peningkatan secara signifikan terhadap sikap rasa ingin tahu siswa dan hasil belajar siswa. Model pembelajaran flipped classroom dapat direkomendasikan sebagai salah satu model pembelajaran untuk meningkatkan sikap rasa ingin tahu siswa. Keberhasilan pada penelitian ini terlihat dari tercapainya indikator sikap rasa ingin tahu.

\section{REFERENSI}

Agustian, U., Prambudi, A., \& Hidayah, I. (2019). Meningkatkan Kemampuan Berpikir Kreatif dan Rasa Ingin Tahu Melalui Model DL Berbantuan Kartu 
Domino Materi Operasi Bilangan Pecahan Kelas VII. Jurnal Prisma, 2(2), 778-787.

Alita, K. U., Koeswanti, H. D., \& Giarti, S. (2019). Penerapan Model Problem Based Learning Untuk Meningkatkan Kemampuan Berpikir Kritis Siswa Kelas V Sdn Ledok 5 Tahun Pelajaran 2018/2019. Jurnal Basicedu, 3(1), 169-173. https://doi.org/10.31004/basicedu.v3 i1.115

Asri, A. N., Widowati, T., \& Roisatin, U. A. (2018). Implementasi Flipped Classroom Dalam Pengajaran Bahasa Inggris Di Jurusan Teknologi Informasi. Jurnal Ilmiah Edukasi \& Sosial, 9(September), 106-116. Retrieved from http://jiesjournal.com/index.php/jies /article/view/142/108

Chandra, F. H., \& Nugroho, Y. W. (2017). Implementasi Flipped Classroom Dengan Video Tutorial Pada Pembelajaran Fotografi Komersial. Desain Komunikasi Visual, Manajemen Desain Dan Periklanan (Demandia), 4(2), 20. https://doi.org/10.25124/demandia.v $2 \mathrm{i} 01.772$

Diana, P., Marethi, I., \& Pamungkas, A. S. (2020). Kemampuan Pemahaman Konsep Matematis Siswa: Ditinjau dari Kategori Kecemasan Matematik. SJME (Supremum Journal of Mathematics Education), 4(1), 24-32.

Febriani, S., Taufik, M., \& Verawati, N. (2019). Pengaruh Model Guided Discovery Learning Dengan Metode Eksperimen Terhadap Hasil Belajar Fisika Peserta Didik MAN 1 Mataram Ditinjau Dari Gaya Belajar VAK. Jurnal Pendidikan Fisika dan Teknologi, 5(1), 82-90. doi: http://dx.doi.org/10.29303/jpft.v5i1. 872

Fitria, H., Kristiawan, M., \& Rahmat, N. (2019). Upaya Meningkatkan Kompetensi Guru Melalui Pelatihan Penelitian Tindakan Kelas. Abdimas Unwahas, 4(1), 14-25. https://doi.org/10.31942/abd.v4i1.26 90

Haryanto, E. (2019). Upaya Meningkatkan Rasa Ingin Tahu Dan Prestasi Belajar Matematika Materi Sifat-Sifat Bangun Ruang Melalui Model Pembelajaran Van Hiele Di Kelas V Sd Muhammadiyah 04 Comal. Dinamika Jurnal Ilmiah Pendidikan Dasar, 9(2), 53-56. https://doi.org/10.30595/dinamika.v 9i2.3862

Ishak, Thanthwi; Kurniawan, Rudi; Zainuddin, Z. (2019). Implementasi Model Pembelajaran Flipped Classroom Guna Meningkatkan Interaksi Belajar Mahasiswa pada Mata Kuliah Manajemen Informasi dan E-Administrasi. Edcomtech: Jurnal Kajian Pendidikan, 3(2), 109-119.

Lidiana, H., Gunawan, G., \& Taufik, M. (2018). Pengaruh Model Discovery Learning Berbantuan Media PhET Terhadap Hasil Belajar Fisika Peserta Didik Kelas XI SMAN 1 Kediri Tahun Ajaran 2017/2018. Jurnal Pendidikan Fisika dan Teknologi, 4(1), 33-39. doi: http://dx.doi.org/10.29303/jpft.v4i1. 519

Listriania, N. D., \& Aini, K. N. (2019). Pengaruh Pembelajaran Kontekstual Berbantuan Hands Activity terhadap Kemampuan Pemecahan Masalah Matematik dan Rasa Ingin Tahu Siswa. Jurnal Inovasi Pendidikan Dan Pembelajaran Matematika, 5(1), 50-61. 
Nasution, M. (2018). Konsep Pembelajaran Matematika Dalam Mencapai Hasil Belajar Menurut Teori Gagne. Logaritma: Jurnal Ilmu-Ilmu Pendidikan Dan Sains, 6(02), 112126.

https://doi.org/10.24952/logaritma.v 6i02.1280

Nurhasanah, N. (2019). Menggunakan Pendekatan Active Learning Dalam Kewarganegaraan di Sekolah Dasar. Jurnal Dinamika Sekolah Dasar, 1(5), 1-10.

Nurpianti, S., Fany, A., \& Wijaya, C. (2019). Implementasi Model Flipped Classroom berbasis Pendidikan untuk Pembangunan Berkelanjutan (PPB) dalam Meningkatkan Keterampilan Berpikir Kritis. Prosiding Seminar Nasional Fisika 2019, 0, 208-214.

Prasetyo, T., \& Nisa, K. (2018). Pengaruh Model Problem Based Learning Terhadap Hasil Belajar Dan Rasa Keingintahuan Siswa. Didaktika Tauhidi: Jurnal Pendidikan Guru Sekolah Dasar, 5(2), 83. https://doi.org/10.30997/dt.v5i2.110 3

Rahajeng, N. K. A, Santyasa, I. W. \& Suswandi, I. (2018). Pengaruh Model Pembelajaran Group Investigation Menggunakan Outdoor Study Terhadap Kemampuan Berpikir Kritis Siswa SMAN 10 Malang. JPPF (Jurnal Pendidikan Dan Pembelajaran Fisika), 8(1), 80 100.

Rani, S. (2018). Implementasi Flipped Classroom Learning Strategi Meningkatkan Higher Order Thinking Mahasiswa. JIPE (Jurnal Inovasi Pendidikan Ekonomi), 8(1), 39-48.

Setiyadi, D. (2018, February). Upaya Meningkatkan Rasa Ingin Tahu dan
Prestasi Belajar Berbantukan Lembar Kerja Siswa Lambang Bilangan Romawi Melalui Strategi TANDUR di Kelas IV Sekolah Dasar. In PRISMA, Prosiding Seminar Nasional Matematika (Vol. 1, pp. 954-962).

Waluyo, S. B., \& Siswanto, B. (2019). Upaya Meningkatkan Kemampuan Pemahaman Konsep Matematis dan Rasa Ingin Tahu Siswa Kelas X MIPA 9 SMA N 4 Semarang Melalui Model Problem Based Learning Berbantuan Kartu Soal. Prima: Jurnal Pendidkan Matematika, 2, 893-898.

Widiawati, S., Hikmawati, H., \& Wahyudi, W. (2018). Pengaruh Model Pembelajaran Kooperatif Tipe Group Investigation (GI) Terhadap Hasil Belajar Fisika Ditinjau dari Gaya Belajar Siswa. Jurnal Pendidikan Fisika Dan Teknologi, 4(1), 40-48. https://doi.org/10.29303/jpft.v4i1.45 9

Widodo, S. (2017). Peningkatan Komunikasi Matematis Mahasiswa Calon Guru Sd Melalui Implementasi Flipped Classroom. Jurnal Euclid, 4(2), 790-798. https://doi.org/10.33603/e.v4i2.316 